\title{
The Effect Of IFRS Adoption On Global Market Integration
}

Francis Cai, William Paterson University, USA

Hannah Wong, William Paterson University, USA

\begin{abstract}
This paper examines the effect of the adoption of international financial accounting standards (IFRS) on global capital market integration, measure by correlation matrix of the stock market index returns. We investigate a sample of countries that have adopted IFRS as their accounting standards for listed companies. Our results are consistent with the suggestion that these markets will have a higher degree of integration among them after their IFRS adoption as compared to the period before the adoption.
\end{abstract}

Keywords: IFRS, Integration, Correlation, Market Indices, Adoption, G8

\section{INTRODUCTION}

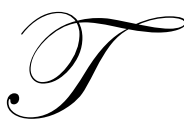

he purpose of this paper is to empirically examine the effect of the adoption of international financial accounting standards (IFRS) on global capital market integration. To make well-informed decisions regarding their internationally diversified portfolios, investors need to compare the financial performance of companies in different countries. However, this is a difficult task due to the great diversity in financial reporting practices among countries [Choi and Levich 1991, Adhikari et al. 2002]. As a result, crosslisting companies are often required to restate their financial statements from their local generally accepted accounting principles (GAAP) to the GAAP of the jurisdiction where their security is listed [Saudagaran 2000], which is a costly process to the companies.

Having a single set of internationally acceptable financial reporting standards will eliminate the need for restatement of financial statements, yet ensure less accounting diversity among countries, thus facilitates the crossborder movement of capital and greater integration of the global financial markets. As of the end of 2008, over one hundred countries have adopted the International Financial Reporting Standards (IFRS) issued by the International Accounting Standard Board (IASB) as their financial accounting standards.

Our paper is the first study that empirically examines the relationship between IFRS adoption and the subsequent integration of the capital market among countries. We investigate a sample of countries that have adopted IFRS as their accounting standards for listed companies and measure the degree of capital market integration among these countries. Our hypothesis is that these markets will have a higher degree of integration among them subsequent to their IFRS. Our control sample consists of countries that have not adopted IFRS as their accounting standards.

The remainder of the paper is structured as follows: Section Two describes our methodology. Section Three presents the sample data and results. Section Four concludes the paper with suggestions for further research.

\section{RESEARCH METHODOLOGY}

\section{Sample Selection}

There is vast difference among the IFRS adopting countries in terms of their political, social, and economic environment. Samuels and Oliga (1982), Ndubizu (1984), Briston and El-Ashker (1984), Hove (1989), Perera 
(1989) and Hoarau (1995) suggest that characteristics and information needs of developing countries differ greatly from that of developed countries. Therefore the exact effect of IFRS adoption on a country's integration into the international financial community may be different depending on the country's political and economic environment. To mitigate this problem, we restrict our sample to the developed countries. Specifically, we focus on the G8 countries: Canada, France, Germany, Italy, Japan, Russia, The United Kingdom and The United States. All things being equal, a small sample size reduces the power of our empirical tests, thus results in a greater tendency to reject our hypothesis even if it is true.

Among the sample countries, France, Germany, Italy and The United Kingdom all adopted IFRS in 2005 as members of the European Union. The other G8 members have not adopted IFRS as of November 30th, 2008, the end of our sample period. Canada has announced its plan to adopt IFRS by 2011. Japan reached an agreement with the IASB to converge Japanese GAAP and IFRS by June 2011. In the United States, the SEC announced the Roadmap for convergence, under which it expects to make the final decision on IFRS adoption in 2011.

\section{Measure of Capital Market Integration}

\section{a. Stock Market Indices}

Since the classic paper by Bekaert and Harvey (1995), many studies in the finance literature measure global market integration by using correlations among stock market indices. A higher correlation coefficient between two stock indices indicates that the stock prices of the two markets tend to move in the same direction, thus implying a greater degree of integration. Bekaert and Harvey (1995) examine market integration using a sample of 12 emerging markets and the developed markets comprising the Morgan Stanley Capital International (MSCI) index. More recent research include Heston and Rouwenhorst (1994), Aydemir (2004), Goetzmann, Li and Rouwenhorst (2004), Chambet and Gibson (2006), and Eiling and Gerard (2007).

We use this widely accepted approach to measure the integration among our sample countries. For each country, we use the index which is most widely accepted as representative of the equity market in that country. If there are two or more commonly cited indices, we choose the index whose number of constituent companies is closer to 100 , to enhance homogeneity among the sample indices.

For the four IFRS adopting countries, we use the SBF 120 index for France, Dax for Germany, MIBTEL for Italy, and FTSE 100 for the United Kingdom. For the non-adopting countries, we use the S\&P/TSX 60 index for Canada, NIKKEI 225 for Japan, RTS for Russia, and S\&P 100 for the United States. Our data consists of the daily level of each index from January $1^{\text {st }}, 1999$ to November $30^{\text {th }}, 2008$.

\section{b. $\quad$ Correlation Coefficient}

The daily index level is available from DataStream, which is denominated in local currency. To ensure consistency in measurement, we compute all index returns in U.S. dollars. We convert the daily index level of country $i$ on day $t$ into U.S. dollar using the exchange rate for the local currency of country $i$ on the same day:

$\mathrm{P}_{\mathrm{it}}{ }^{\mathrm{us}}=\mathrm{P}_{\mathrm{it}}{ }^{\mathrm{i}} \times \mathrm{E}_{\mathrm{it}}$

The exchange rate data is also collected from DataStream. Then we calculate the rate of return of country i's stock index $\left(\mathrm{R}_{\mathrm{it}}\right)$ as:

$\mathrm{R}_{\mathrm{it}}=\ln \left(\mathrm{P}_{\mathrm{it}}\right.$ us $\left./ \mathrm{P}_{\mathrm{it}-1}{ }^{\text {us }}\right)$

where $\ln$ is the natural logarithm operator.

Next, we divide the sample period into pre IFRS-adoption period, which includes January $1^{\text {st }}, 1999$ to December 31, 2004, and post IFRS-adoption period, which is from January $1^{\text {st }}, 2005$ to November $30^{\text {th }}$, 2008. Finally, the Pearson correlation coefficients among all the country index returns are calculated. The correlation coefficients among the 
IFRS adopting countries are compared with the correlation coefficients among non-adopting countries, as well as correlation coefficients between an adopting and non-adopting country.

\section{DATA AND RESULTS}

Table 1 shows the industry composition of the stock price indices. Panel A shows the number of companies in each industry, while Panel B shows the industry composition in percentage of the local market. There are a total of 975 sample firms. Most firms belong to one of the four sectors: industrials (manufacturing), financials, consumer goods and consumer services. The four sectors make up over $65 \%$ of the sample companies (637 companies out of 975 companies). Some industries are absent in certain local capital markets. Germany has no oil and gas company, while Russia does not have healthcare or technology stocks. In fact, it seems countries tend to specialize in different industries. Over $28 \%$ of Japan's Nikkie index is made of manufacturing firms. Manufacturing and the financial sectors make up over 30\% of the S\&P 100 index. And the United States is the country with the highest percentage of technology firms.

Table 2 presents descriptive statistics for the daily stock index returns calculated using equations (1) and (2). For each stock index, there are a total of 3435 observations from the time period September $1^{\text {st }}, 1995$, which is the inception of the Russian RTS index, to November $30^{\text {th }}$, 2008. The pre IFRS adoption period consists of 2435 observations whereas the post IFTS adoption period consists of 1000 observations. The return patterns are similar among different countries, except Russia. The RTS index return has a higher average return and greater volatility than all other market indices. In fact, both the mean and the standard deviation of its returns roughly double their counterparts of other countries.

Table 3 shows the correlation matrix for the daily index returns in the pre IFRS-adoption period and post IFRS-adoption period. In both periods, the correlation coefficients between two adopting countries are higher than the coefficients between two non IFRS-adopters countries or between an adopter and a non-adopter. Almost all pairs of countries have a higher correlation in the post adoption period. ${ }^{1}$ The change among adopting countries ranges from 0.13 to 0.26 . The average increase is 0.1966 . The changes in the correlation coefficients among all other pairs of countries have an average change of 0.1101 .

Table 4 plots the quarterly cross-country correlations before and after the IFRS adoption from 1999 to 2008. There seems to be significant variation in the correlation structure between the adopters and non-adopters. For each adopting country, its correlation with other adopters is much higher than that of its correlation with nonadopters. In fact, the difference in correlation is so great that the trend lines do not overlap. Similar pattern is not present for the non adopting countries. This is not surprising since the adopters consist of the three European countries and the United Kingdom, which are politically and economically more homogenous than the non adopters. Our research question is: Is there a difference between the adopting and non adopting group in terms of the variation in the correlation structure around the IFRS adoption by the European Union in 2005? Specifically, is the IFRS adoption followed by a significant increase in correlation among the adopters as compared to non-adopters?

To test this hypothesis, we use the cross-country correlations which involve at least one non-adopter as the control sample. For each quarter, we calculate the average correlation for the adopting group and the control group. The difference between the two averages is computed. Mean difference in the pre-adoption period is 0.24 , while that in the post-adoption period is 0.32. The null hypothesis that the difference is of the same magnitude before and after the IFRS adoption is rejected at less than 1\% interval. Therefore although all countries show greater integration with each other over time, compared to their non adopting counterparts, the IFRS adopting countries seem to enjoy a greater integration of their capital market after the IFRS adoption.

\footnotetext{
${ }^{1}$ The only exceptions are correlation between Canada and the United States, which decreased from 0.63 to 0.57 , and the correlation between Japan and the United States, which changed from 0.07 to -0.10 .
} 


\section{CONCLUSION}

This paper is a first attempt to empirically measure the effects of IFRS adoption on a stock market's integration into the global capital market. The results are consistent with the widely suggested benefit of IFRS adoption. Adopting IFRS seems to reduce the diversity of accounting practices, thus enables the efficient movement of capital across borders. This paper is particularly relevant in light of the SEC's Roadmap for convergence, as announced in November 2008. The SEC will make a final decision in 2011 as to whether it will require U.S. companies to prepare their financial statements using the international accounting standards. Our results provide support for the adoption of such standards.

Table 1

Industry Composition by Countries

Industry composition of the constituent securities of individual country indices as of November $30^{\text {th }}, 2008$.

Panel A: Number of companies in each industry.

$\begin{array}{lcccccccc}\text { Country: } & \text { France } & \text { Germany } & \text { Italy } & \text { Kingdom } & \text { Canada } & \text { Japan } & \text { Russia } & \text { United States } \\ \text { Market Index: } & \text { SBF120 } & \text { DAX30 } & \text { MIBTEL } & \text { FTSE100 } & \text { TTO60 } & \text { NIKKEI } & \text { RTS } & \text { S\&P100 } \\ \text { Oil \& Gas } & 5 & 0 & 6 & 9 & 12 & 4 & 11 & 9 \\ \text { Basic Materials } & 6 & 4 & 8 & 11 & 14 & 32 & 13 & 3 \\ \text { Industrials } & 26 & 7 & 65 & 10 & 4 & 64 & 1 & 14 \\ \text { Consumer Goods } & 17 & 6 & 56 & 8 & 2 & 46 & 3 & 12 \\ \text { Healthcare } & 6 & 2 & 8 & 4 & 2 & 10 & 0 & 12 \\ \text { Consumer Services } & 20 & 2 & 35 & 20 & 9 & 22 & 4 & 9 \\ \text { TELECOMMUNICATIONS } & 1 & 1 & 6 & 3 & 3 & 4 & 8 & 3 \\ \text { Utilities } & 7 & 2 & 18 & 8 & 3 & 5 & 6 & 6 \\ \text { Financials } & 21 & 7 & 64 & 26 & 9 & 26 & 4 & 18 \\ \text { Technology } & 10 & 2 & 21 & 3 & 2 & 12 & 0 & 13 \\ & 119 & 33 & 287 & 102 & 60 & 225 & 50 & 99\end{array}$

Panel B: Percentage of companies in each industry.

\begin{tabular}{lcccccccc}
\hline & & & & & \multicolumn{2}{c}{ United } \\
Country: & Canada & France & Germany & Italy & Japan & Russia & Kingdom & United States \\
Market Index: & TTO60 & SBF120 & DAX30 & MIBTELI & NIKKEI & RTS & FTSE100 & S\&P100 \\
Oil \& Gas & 0.2000 & 0.0420 & 0.0000 & 0.0209 & 0.0178 & 0.2200 & 0.0882 & 0.0909 \\
Basic Materials & 0.2333 & 0.0504 & 0.1212 & 0.0279 & 0.1422 & 0.2600 & 0.1078 & 0.0303 \\
Industrials & 0.0667 & 0.2185 & 0.2121 & 0.2265 & 0.2844 & 0.0200 & 0.0980 & 0.1414 \\
Consumer Goods & 0.0333 & 0.1429 & 0.1818 & 0.1951 & 0.2044 & 0.0600 & 0.0784 & 0.1212 \\
Healthcare & 0.0333 & 0.0504 & 0.0606 & 0.0279 & 0.0444 & 0.0000 & 0.0392 & 0.1212 \\
Consumer Services & 0.1500 & 0.1681 & 0.0606 & 0.1220 & 0.0978 & 0.0800 & 0.1961 & 0.0909 \\
Telecommunications & 0.0500 & 0.0084 & 0.0303 & 0.0209 & 0.0178 & 0.1600 & 0.0294 & 0.0303 \\
Utilities & 0.0500 & 0.0588 & 0.0606 & 0.0627 & 0.0222 & 0.1200 & 0.0784 & 0.0606 \\
Financials & 0.1500 & 0.1765 & 0.2121 & 0.2230 & 0.1156 & 0.0800 & 0.2549 & 0.1818 \\
Technology & 0.0333 & 0.0840 & 0.0606 & 0.0732 & 0.0533 & 0.0000 & 0.0294 & 0.1313 \\
& 1 & 1 & 1 & 1 & 1 & 1 & 1 & 1 \\
\hline
\end{tabular}


Table 2

Descriptive Statistics of Daily Returns of Stock Market Indices

Daily market indices are restated in U. S. dollars. Then the rates of return are computed using continuous compounding. The sample period is from September $1^{\text {st }}, 1995$ to November $30^{\text {th }}, 2008$.

\begin{tabular}{lcccccc}
\hline Country & Market Index & \#Obs. & Mean & Std Dev & Minimum & Maximum \\
\hline Canada & TTO60 & 3435 & 0.0002930 & 0.01331 & -0.10525 & 0.12388 \\
France & SBF120 & 3435 & 0.0001900 & 0.01346 & -0.11642 & 0.11439 \\
Germany & DAX30 & 3435 & 0.0002323 & 0.01516 & -0.09594 & 0.11394 \\
Italy & MIBTEL & 3435 & 0.0001362 & 0.01298 & -0.10861 & 0.11111 \\
Japan & NIKKEI & 3435 & -0.0002208 & 0.01645 & -0.13897 & 0.13676 \\
Russia & RTS & 3435 & 0.0005955 & 0.02797 & -0.21199 & 0.20204 \\
U.K. & FTSE100 & 3435 & 0.0000735 & 0.01266 & -0.09795 & 0.10108 \\
U.S. & SP100 & 3435 & 0.0001616 & 0.01224 & -0.09186 & 0.10655 \\
\hline
\end{tabular}

Table 3

Correlation Coefficients for the Pre and Post IFRS-adoption periods

The Pearson correlation coefficients are calculated using daily index returns. The upper half of the table contain the correlation coefficients in the pre IFRS-adoption period whereas the lower half shows the correlation coefficients in the post IFRS-adoption period. Shaded numbers represent the correlation between two IFRS adopters.

\begin{tabular}{lcccccccc}
\hline Country & Canada & France & Germany & Italy & Japan & Russia & United Kingdom & United States \\
Market Index & TTO60 & SBF120 & DAX30 & MIBTEL & NIKKEI & RTS & FTSE100 & SP100 \\
Canada & 1 & 0.44995 & 0.46671 & 0.38068 & 0.17516 & 0.20592 & 0.39268 & 0.63365 \\
France & 0.61424 & 1 & 0.78614 & 0.59829 & 0.21672 & 0.25548 & 0.72479 & 0.38526 \\
Germany & 0.56545 & 0.91503 & 1 & 0.68291 & 0.18307 & 0.25271 & 0.63292 & 0.44769 \\
Italy & 0.59453 & 0.77651 & 0.87768 & 1 & 0.17311 & 0.23267 & 0.61782 & 0.32045 \\
Japan & 0.24024 & 0.35251 & 0.3177 & 0.36287 & 1 & 0.13979 & 0.21732 & 0.06666 \\
Russia & 0.44022 & 0.56151 & 0.50512 & 0.55226 & 0.36719 & 1 & 0.25486 & 0.13179 \\
U.K. & 0.64601 & 0.91505 & 0.85846 & 0.87977 & 0.31619 & 0.54516 & 1 & 0.33106 \\
U.S. & 0.56582 & 0.44065 & 0.48911 & 0.39003 & -0.01 & 0.20182 & 0.49662 & 1 \\
\hline
\end{tabular}

Table 4

Quarterly Correlation by Country

The quarterly correlation coefficients between the stock indices are calculated from 1999 to 2008. Each diagram depicts the average correlation of each country with its IFRS-adopting counterparts as well as that with non IFRS-adopters.

\section{Panel A: IFRS Adopters and Their Correlation with Other Countries}

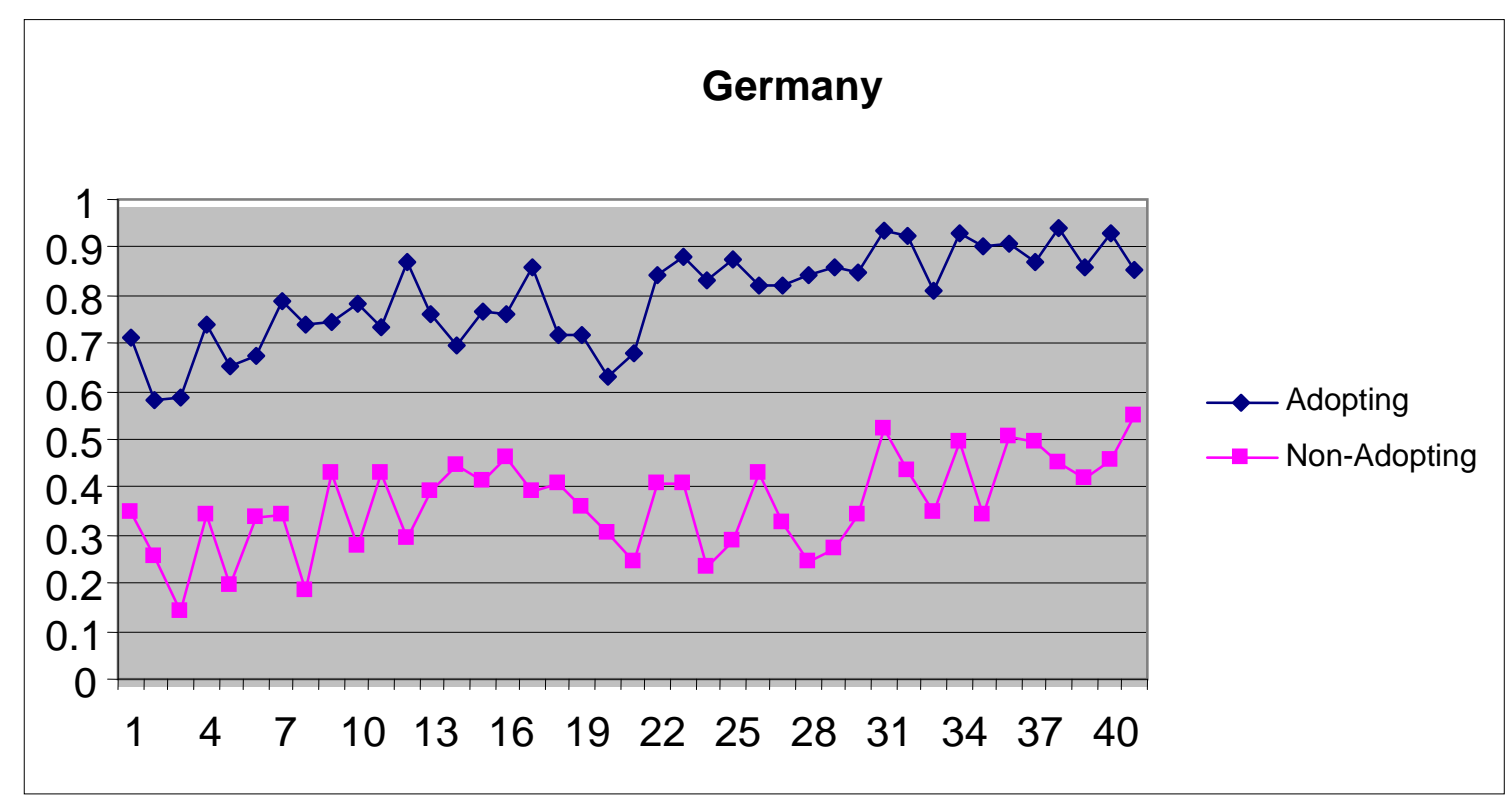



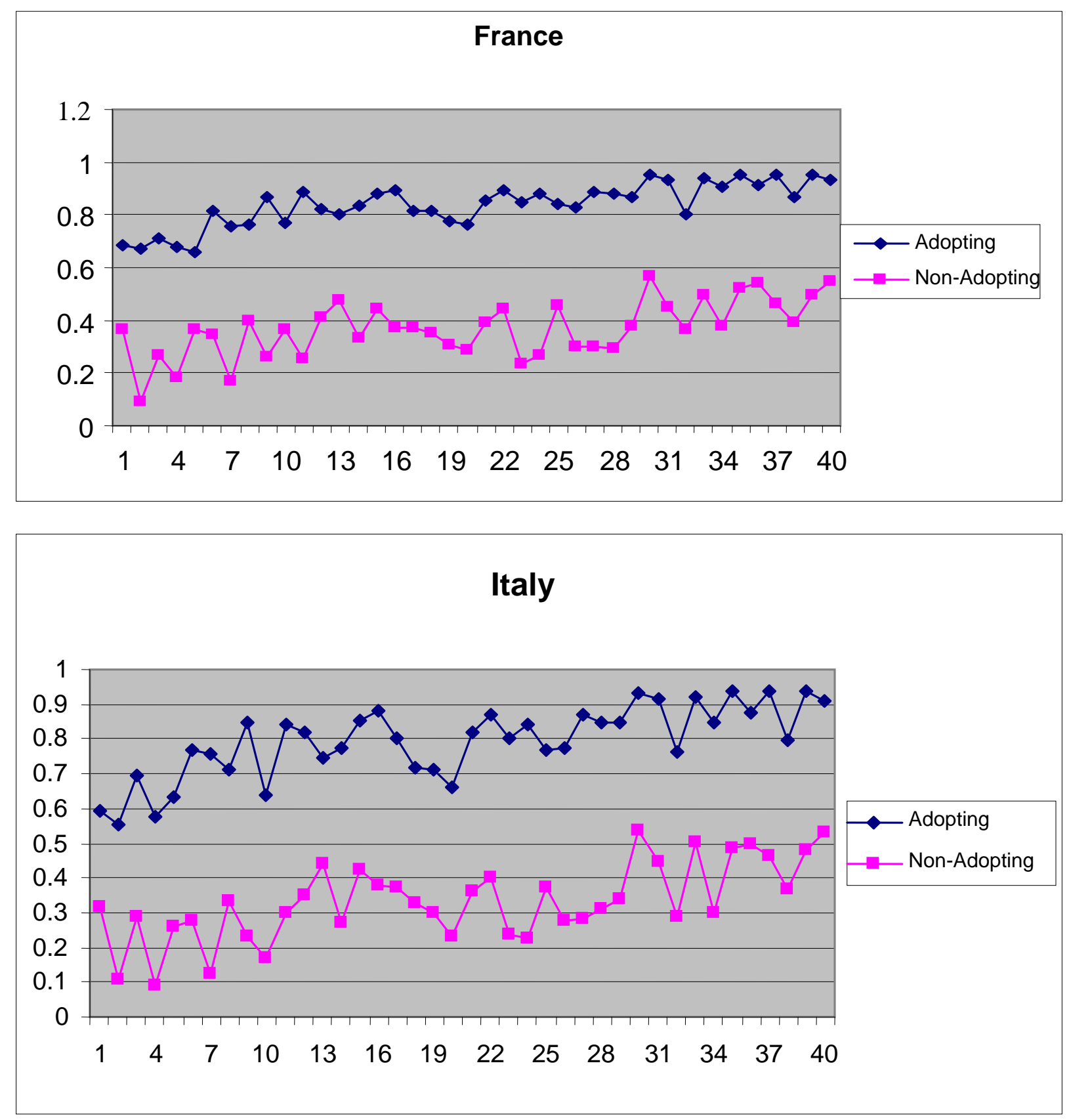


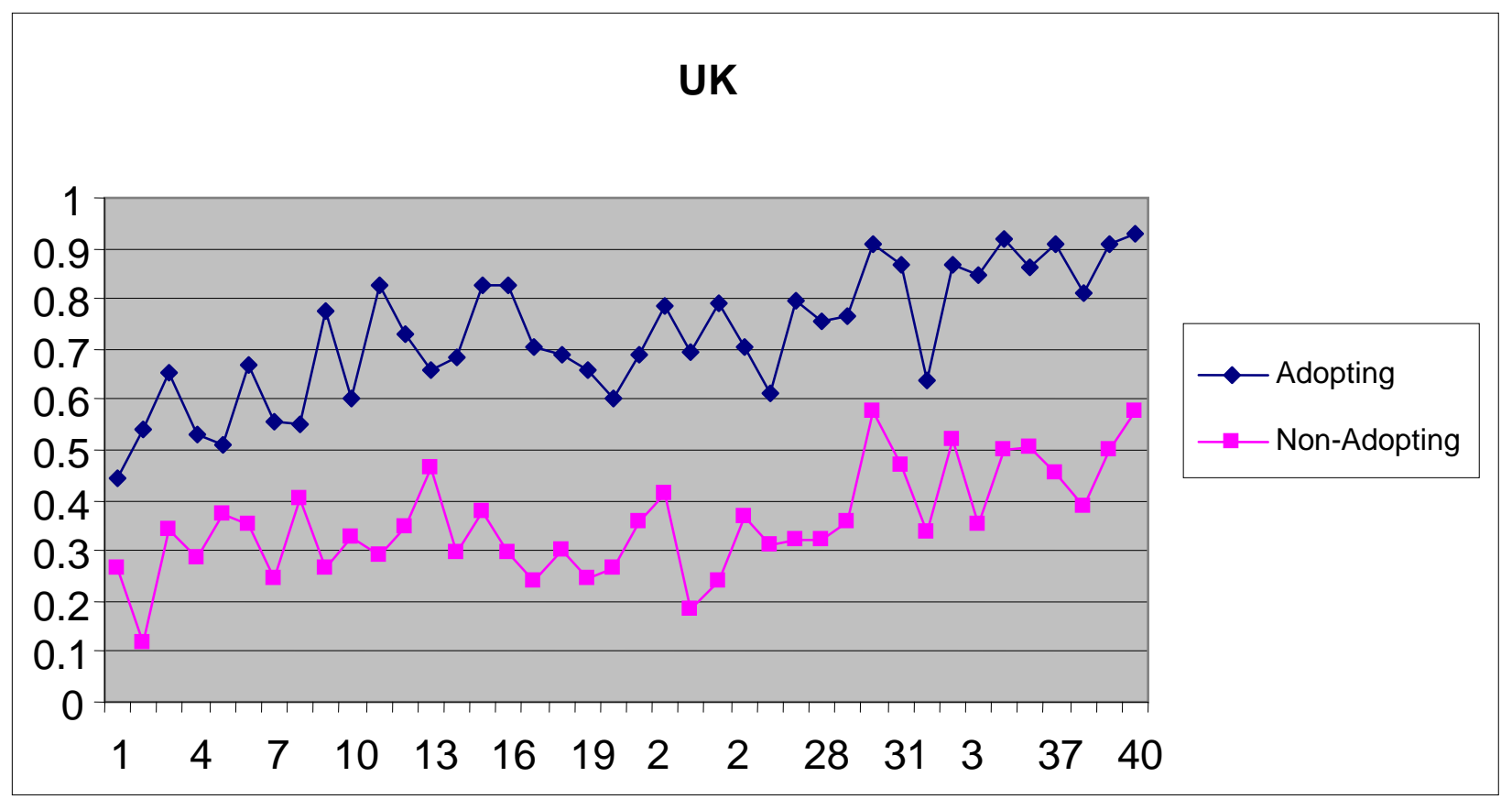

Panel B: IFRS Non-Adopters and Their Correlation with Other Countries

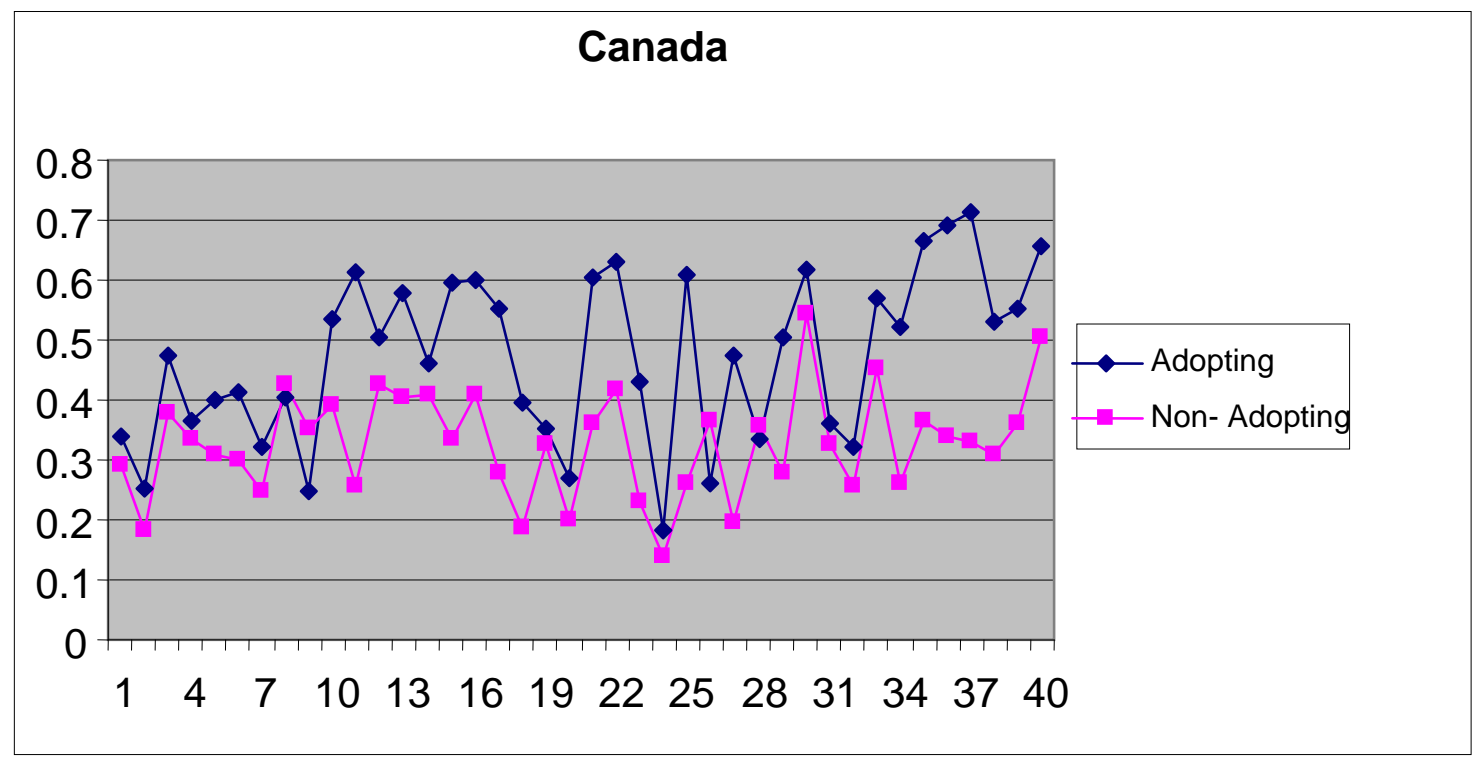



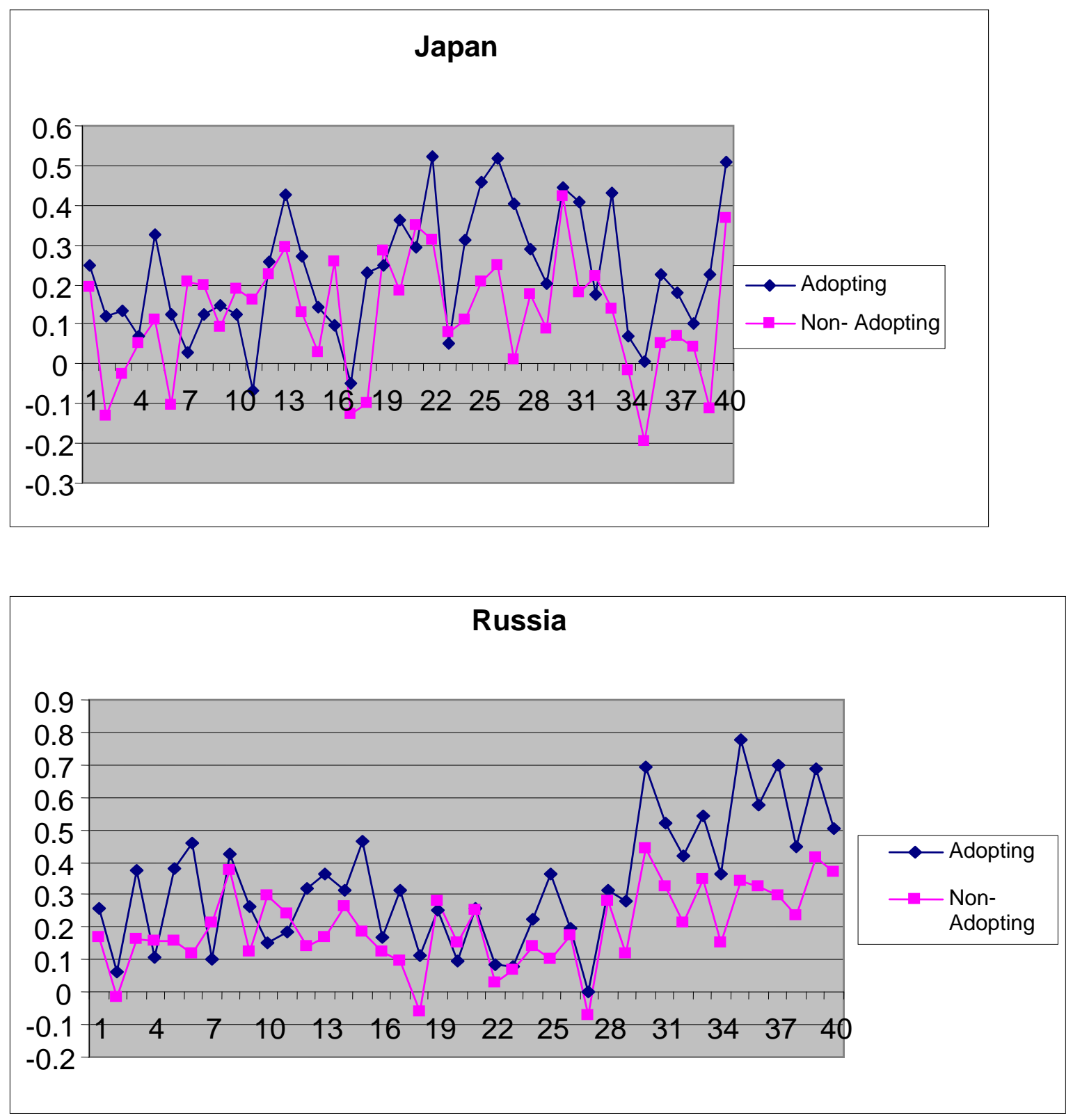


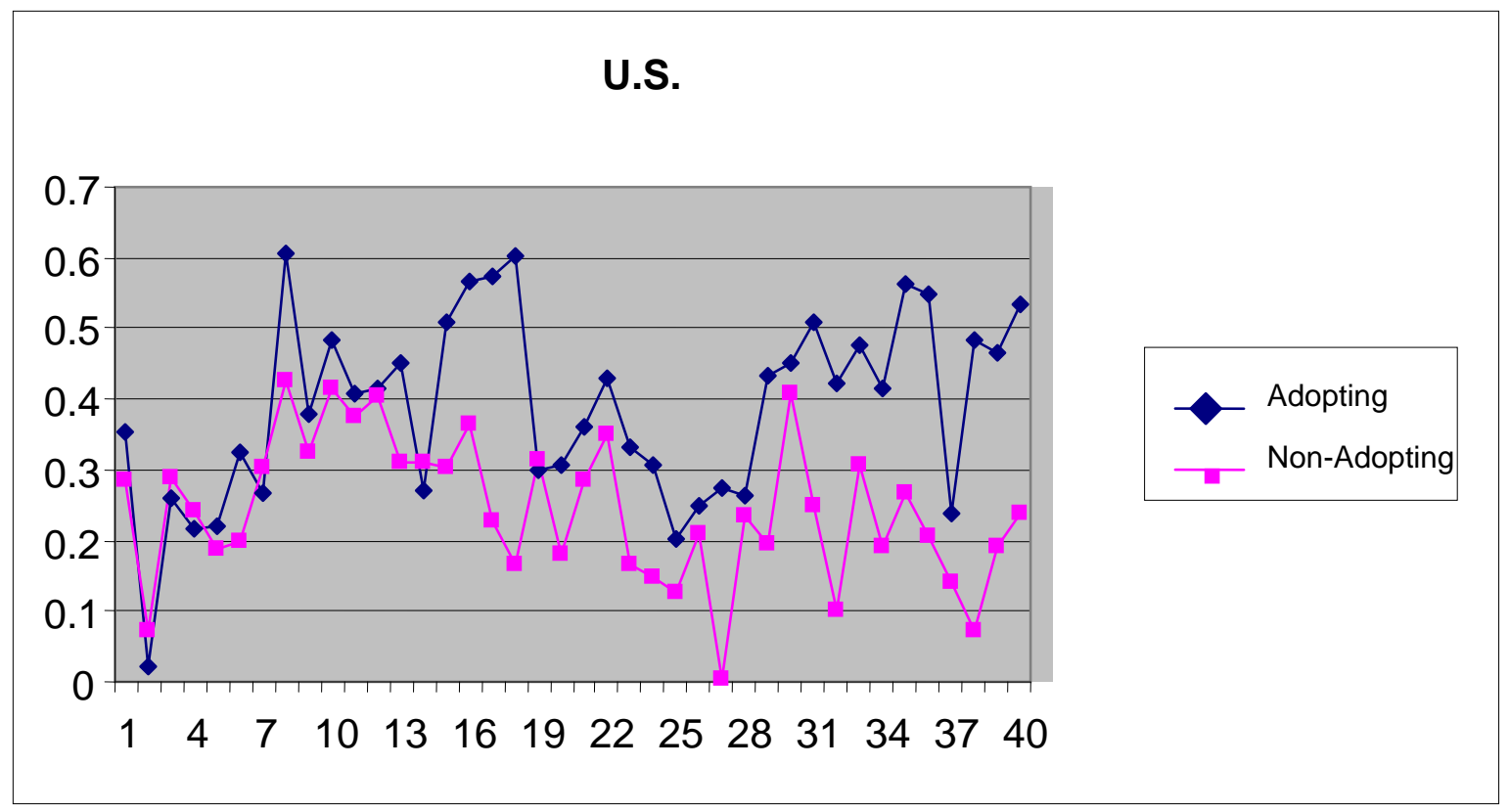

\section{AUTHOR INFORMATION}

Professor Francis Cai received his doctoral degree from the City University of New York in 1990. He is currently a professor of finance and director of the MBA program in the Cotcakos College of Business, William Paterson University. His primary research interests include studying the behavior of emerging markets, investigating the earnings and stock return models, and modeling foreign direct investment and economic growth. He is the author of over 20 articles published in premium scholarly journals such as Journal of Business and Economics Research, Competition Forum, Journal of Business and Economic Studies, and Journal of Global Competitiveness.

Dr. Hannah Wong received her Ph.D. degree from University of California, Los Angeles (UCLA) in 1996. She was an assistant professor at Rutgers University and the controller of DataSoft Solutions, Inc., a consulting company, before she joined the Accounting department of the Cotcakos College of Business, William Paterson University. Her research focuses on reporting and valuation issues of global financial markets and integration of international accounting standards. She has been an active presenter in various conferences such as the FMA national meetings and AAA regional meetings. She has published in various proceedings and journals, including Journal of International Accounting Research, an academic journal of American Accounting Association.

\section{REFERENCES}

1. Adhikari, A., R.H.Tondkar, and J.A.Hora. An analysis of international accounting research in Journal of International Accounting, Auditing and Taxation. Journal of international Accounting, Auditing and Taxation Research 11:39-49, 2002.

2. Aydemir, C. Why are international equity market correlations low? Working paper, Carnegie Mellon University, 2004.

3. Barth, M., Landsman, W. and Lang, M. International accounting standards and accounting quality. Journal of Accounting Research 46 (3): 467-500, 2008.

4. Bekaert, G., Harvey, C. Time varying world market integration. Journal of Finance 50: 403-444, 1995.

5. Briston, R.J. and A. El-Ashker. The evolution of accounting in developing countries. International Journal of Accounting 19:129-156, 1984.

6. Chambet, A., and R. Gibson. Financial integration, economic instability, and trade structure in emerging markets. Journal of International Money and Finance, 27 (4):654-675, 2008. 
7. Choi, F.D.S. and R. M. Levich. The Capital Market Effects of International Accounting Diversity. Illinois: Dow Jones-Irwin, 1990.

8. Eiling, E. and B. Gerard. Dispersion, equity returns correlations and market integration. Working Paper. University of Toronto, 2007.

9. Heston, S. and K. G. Rouwenhorst. Does industrial structure explain the benefits of international diversification? Journal of Financial Economics 36: 3-27, 1994.

10. Hoarau, C. International accounting harmonization; American hegemony or mutual recognition with benchmarks. European Accounting Review 4(2); 217-234, 1995.

11. Hove, M. R. The inappropriate uses of international accounting standards in less developed countries; The case of International Accounting Standard No. 24 - Related party disclosures concerning transfer prices. International Journal of Accounting 24 (2); 165-179, 1989.

12. International Organization Of Securities Commissions (IOSCO). A Resolution on IASC Standards. Presidents' Committee of IOSCO. Madrid, Spain: IOSCO, 2000

13. Ndubizu, G. A. Accounting standards and economic development: The Third World in perspective. International Journal of Accounting 19 (2): 181-196, 1984.

14. Perera, M. H. B. Accounting in developing countries: A case for localized uniformity. The British Accounting Review 21 (2): 41-57, 1989.

15. Pukthuanthong-Le, K. and R. Roll. Working Paper, UCLA, 2008.

16. Samuels, J. M. and J. C. Oliga. Accounting standard in developing countries. The International Journal of Accounting 18 (1): 69-87, 1982.

17. Saudagaran, S. M. International Accounting: A User Perspective. South-Western College Publishing, 2000. 